\title{
IMPLEMENASI KEBIJAKAN PENDIDIKAN DASAR DAERAH KEPULAUAN (Studi di Kabupaten Kepulauan Talaud Provinsi Sulawesi Utara)
}

\author{
Very Y. Londa \\ Program Studi Ilmu Administrasi Negara, Fakultas Ilmu Sosial dan Politik Universitas Sam Ratulangi \\ E-mailv312yjlo@yahoo.com
}

\begin{abstract}
ABSTRAK. Kabupaten Kepulauan Talaud yang memiliki 20.209 jiwa penduduk usia sekolah atau 24.38\% dari jumlah penduduk menghadapi permasalahan yang antara lain kurangnya guru yang bersedia ditempatkan di daerah, kurangnya sarana fisik baik berupa gedung, alat peraga bidang studi, peralatan laboratorium, buku-buku pelajaran dan peralatan pelajar lainnya; tidak lengkapnya data kependidikan untuk menunjang program on-line jardiknas. Penelitian ini bertujuan menjelaskan proses implementasi kebijakan pendidikan dasar dalam pengembangan ilmu administrasi publik dan penyelesaian permasalahan pendidikan dasar di Kabupaten Kepulauan Talaud. Melalui penggunaan desain kualitatif penelitian ini menemukan bahwa sekalipun implementasi kebijakan pendidikan dasar di Kabupaten Kepulauan Talaud pada dimensi idealised policy, Implementing organization dan Environmental faktor khusunya lingkungan lembaga politik. Akan tetapi telah memberikan keberhasilan dalam peningkatan nilai rata-rata mata pelajaran. Serta terjadi peningkatan lulusan maupun prestasi lainnya yang diperoleh peserta didik dalam berbagai perlombaan baik dalam kategori kedaerahan, Provinsi maupun tingkat nasional. Situasi inilah yang oleh peneliti dianggap memiliki keunikan dimana dalam situasi dana yang terbatas, daerah tertinggal dan perbatasan, capaian prestasi pendidikan meningkat.
\end{abstract}

Kata kunci: Implementasi Kebijakan, Pendidikan Dasar, Daerah Kepulauan.

\begin{abstract}
Talaud Islands which has 20209 inhabitants of school age, or $24.38 \%$ of the population face problems that include a lack of teachers who would be placed in the area, lack of physical facilities such as buildings, props field studies, laboratory equipment, textbooks and equipment other students; incomplete data is education to support the on-line program jardiknas. This study aims to explain the basic education policy implementation process in the development of public administration and completion of primary education problems in the Talaud Islands. Through the use of qualitative design of the study found that even basic education policy implementation in the Talaud Islands in idealized dimensions of policy, Implementing Environmental organization and environmental factors especially political institutions. But has given the success in increasing the value - average subjects. And an increase in graduates as well as other achievements obtained learners in various competitions both in the category of regional, provincial and national level. This situation by researchers considered unique in a situation where funds are limited, disadvantaged areas and borders, achievement of educational attainment increases.
\end{abstract}

Key words: Policy Implementation, Basic Education, Islands Region.

\section{PENDAHULUAN}

Kebutuhan akan layanan pendidikan merupakan aspek yang sangat penting untuk diberikan oleh pemerintah kepada masyarakat, dengan memperhatikan permasalahan yang mengemuka dalam bidang pendidikan khususnya yang dilakukan oleh pemerintah daerah Kabupaten Kepulauan Talaud, maka peneliti beranggapan bahwa kaian ini urgen untuk di kaji selain dalam upaya pengembangan keilmua khusnya ilmu administrasi dalam menilai kinerja pelayanan pendidikan dasar juga diharapkan dengan hasil penelitian ini dapat menjadi masukan bagi pemerintah dalam melakukan perbaikan dalam pelayanan pendidikan dasar.

Upaya peningkatan kualitas pendidikan telah dilakukan secara serius oleh pemerintah pusat dan daerah. Ini sejalan dengan amanat Undang-Undang Sistim Pendidikan Nasional No. 20 tahun 2003 pasal 34 yang berbunyi bahwa pemerintah dan pemerintah daerah menjamin terselenggaranya wajib belajar minimal pada jenjang pendidikan dasar tanpa memungut biaya. Undang-Undang di atas dijelaskan lebih lanjut dalam PP No. 47/2008 tentang wajib belajar 9 tahun.
Pendidikan di Kabupaten Kepulauan Talaud ditangani secara langsung oleh Dinas Pendidikan Pemuda dan Olah Raga yang diberikan kewenangan dan tanggung jawab untuk menangani segala hal yang berhubungan dengan pendidikan, kepemudaan dan olahraga mulai dari perumusan kebijakan teknis, penyusunan rencana kerja, pengkoordinasian, pembianaan, pengendalian urusan pemerintahan dan pelayanan bidang pendidikan. Dari jumlah pen-duduk Kabupaten Kepulauan Talaud tahun 2014 yang berjumlah 82.916 jiwa penduduk usia sekolah sebanyak 20.209 jiwa atau $24.38 \%$ dari jumlah penduduk yang terdiri dari usia sekolah TK 2.085, SD 10.01. Dengan 20.209 jiwa penduduk usia sekolah atau 24.38\% dari jumlah penduduk Kabupaten Kepulauan Talaud, Dinas Pendidikan Pemuda dan Olah Raga menghadapi permasalahan yang antara lain 1)kurangnya guru yang bersedia ditempatkan di daerah pedalaman termasuk pulau terluar/kecil; 2) lemahnya kualitas tenaga pengajar baik dalam mengajar, mem-buat bahan ajar dan penyusunan materi; 3) sarana fisik baik berupa gedung, alat peraga bidang studi, peralatan laboratorium, 
buku-buku pelajaran dan peralatan pelajar mengajar yang tidak memadai. Data menun-jukkan dimana dari 364 ruang kelas SD terdapat 84 ruangan kelas rusak ringan dan 68 ruangan kelas rusak berat; 4)tidak adanya data kependidikan untuk menunjang program on-line jardiknas.

Suatu permasalahan yang sangat menarik serta memiliki keunikan dalam dunia pendidikan di Kabupaten Kepulauan Talaud dimana dalam posisi sebagai daerah perbatasan yang sangat kurang sarana dan prasarana penunjang pendidikan serta ditambah dengan tidak tersediannya dana yang cukup dari daerah dalam pembiayaan pendidikan yang dibuktikan dengan adanya dana untuk Dinas Pendidikan Pemuda dan Olahraga yang hanya kurang lebih $11 \%$ dari APBD dimana tidak sesuai dengan amanat undang-undang yang seharusnya mengharuskan daerah untuk menganggarkan dana pendidikan 20\% dari APBD. Kondisi ini ternyata tidak menurunkan semangat insan pendidikan di Kabupaten Kepulauan Talaud untuk meningkatkan kualitas pendidikan yang terbukti dari adanya peningkatan kualitas lulusan pada semua tingkatan pendidikan yang termasuk didalamnya Sekolah Dasar (SD).

Berdasarkan uraian pada latar belakang penelitian yang dikemukakan di atas, maka penelitian ini bertujuan untuk mengungkapkan proses implementasi kebijakan pendidikan Dasar di Kabupaten Kepulauan Talaud sehingga ditemukannya suatu model implementasi kebijakan pendidikan dasar di Kabupaten Kepulauan Talaud. Hasil dari penelitian ini diharapkan memberikan manfaat pada pengembangan keilmuan implementasi kebijakan dalam bidang ilmu sosial ekonomi dan budaya khususnya rumpun ilmu administrasi publik dan memberikan rekomendasi kepada Pemerintah Kabupaten Kepulauan Talaud dalam penyelesaian permasalahan pelayanan public khususnya pada pelayanan pendidikan dasar.

\section{METODE}

Didalam penelitian ini penulis menggunakan desain kualitatif. Penelitian ini diharapkan akan dapat meng-ungkap, menguraikan serta memahami fenomena yang terjadi pada latar dan obyek penelitian. Pilihan pada pendekatan kualitatif dengan argumentasi bahwa kualitatif dapat membantu interpretasi hubungan antara ubahan serta relatif dapat mengungkap alasan bagi hubungan tersebut. Selain itu kualitatif lebih dapat menyentuh secara mendalam aspek behavioral skala kecil, lebih dapat mengungkap rincian kompleks tentang fenomena lapangan. Dengan demikian diharapkan lahirnya preposisi hipotetik baru melalui intrepretasi interaksi antara atribut dan properties yang selanjutnya dapat digunakan untuk membangun kategori dan memberikan eksplanasi terhadap fenomena yang diteliti.

Harapan tersebut dapat terpenuhi melalui pendekatan kualitatif. Tujuannya adalah mengumpulkan data sebagaimana adanya (das sein) menurut persepsi dan pandangan dari semua komponen yang ada di Dinas Pemuda dan Olah Raga yang ada di kantor dinas maupun kantor dinas cabang serta sekolah dasar di lingkup kerja Dinas Pendidikan Pemuda dan Olah Raga Kabupaten Kepulauan Talaud yaitu Kepala Dinas, Kepala Bidang, Kepala Cabang Dinas, kepala sekolah dan guru yang tentu saja didukung dengan referensi teori yang ada.

\section{HASIL DAN PEMBAHASAN}

Studi implementasi masih merupakan cabang dari ilmu administrasi publik. Studi implementasi berusaha untuk menjawab pertanyaan mengapa banyak sekali program pemerintah yang tidak bisa dilaksanakan dengan baik. Implementasi kebijakan merupakan kegiatan yang kompleks dengan begitu banyak faktor yang mempengaruhi keberhasilan suatu implementasi kebijakan. Pandangan tersebut di atas menunjukkan bahwa proses implementasi kebijakan tidak hanya menyangkut perilaku badan-badan administratif yang bertanggung jawab untuk melaksanakan program dan menimbulkan ketaatan pada diri target group, melainkan menyangkut lingkaran kekuatan-kekuatan politik, ekonomi dan sosial yang langsung atau tidak dapat mem-pengaruhi perilaku dari semua pihak yang terlibat, dan pada akhirnya membawa konsekuensi logis terhadap dampak baik yang diharapkan (intended) maupun dampak yang tidak diharapkan (spillover/negatif effects).

Smith (1973:202-205) menunjukkan bahwa terdapat beberapa hal yang perlu untuk diperhatikan, yang dalam hal ini kebijakan diimplementasikan sebagaimana yang dicita-citakan (idealised policy), yakni kebijakannya yang diimplementasikan ke dalam bentuk program-program. Selanjutnya sasaran kebijakan (targets group), yaitu mereka (orang-orang) yang paling langsung dipengaruhi oleh kebijakan dan yang harus mengadopsi pola-pola interaksi sebagaimana yang diharapkan oleh perumus kebijakan. Disamping itu adanya Implementing organization, yaitu badan-badan pelaksana atau unit-unit birokrasi pemerintah yang bertanggung jawab dalam implementasi kebijakan. Serta Environmental factor, yakni unsur-unsur dalam lingkungan yang mempengaruhi atau dipengaruhi oleh implementasi kebijakan, seperti aspek budaya, sosial, ekonomi, dan politik.

Kabupaten Kepulauan Talaud merupakan bagian integral dari Propinsi Sulawesi Utara, beribu kota Melonguane yang berjarak sekitar 271 mil laut dari Ibukota Propinsi Sulawesi Utara yaitu Manado. Terletak antara $3^{\circ} 38^{\prime} 00^{\prime \prime}-5^{\circ} 33^{\prime} 00^{\prime \prime}$ Lintang Utara dan $126^{\circ} 38^{\prime}$ $00^{\prime \prime}-127^{\circ} 10^{\prime} 00^{\prime \prime}$ Bujur Timur. Adapun batas-batasnya adalah Sebelah Utara berbatasan dengan Republik Filipina (P. Mindana ); Sebelah Timur berbatasan dengan Laut Pasifik; Sebelah Selatan berbatasan dengan Kebupaten Kepulauan Sangihe; sebelah Barat berbatasan dengan Laut Sulawesi. Kabupaten Kepulauan Talaud terdiri 
dari 19 (sembilan belas) kecamatan, dimana kecamatan terluas adalah Kecamatan Beo Utara (144,85 KM2) dan kecamatan terkecil adalah Kecamatan Miangas (2,39 KM2). Wilayah administrasi Pemerintahan Daerah Kab. Kepl. Talaud pada keadaan tahun 2010 terbagi dalam 19 Kecamatan, 142 Desa dan 11 Kelurahan dengan jumlah penduduk 83.441 jiwa. Adapun distribusi dan persebaran penduduk di 19 (Sembilan belas) kecamatan.

Untuk jalannya pelaksanaan pendidikan di Kabupaten Kepulauan Talaud dilengkapi dengan lembaga sarana pendidikan sejumlah 264 unit sekolah yang terdiri dari TK 88, SD 115, SMP 40, SMA 13 dan SMK 8. Untuk menjalankan amanat kebijakan dalam pelak-sanaan pendidikan di Kabupaten Kepulauan Talaud, pemerintah daerah menempatkan pegawai di Dinas Pendidikan, Pemuda dan Olah Raga berjumlah 49 orang. Sementara untuk kepala sekolah berjumlah 263, guru tetap 1469, guru tidak tetap 342, pegawai tetap 109 dan pegawai tidak tetap 65, 19 kepala UPTD, 39 pengawas sekolah.

Untuk menjalankan kebijakan angaran pendidikan yang telah ditetapkan dalam segala keterbatasan sementara permasalahan pendidikan yang cukup besar membutuhkan peran serta yang tinggi dari sumber daya manusia yang ada. Sumber daya aparatur Dinas Pendidikan Pemuda dan Olah raga khususnya di Kantor Dinas dengan jumlah 49 orang secara kuantitas dapat dikatakan cukup memadahi untuk mengimplementasikan kebijakan anggaran pendidikan yang ada. Akan tetapi keberadaan aparatur tersebut harus diikuti dengan kemampuan untuk dapat menjalankan dan mengelolah keuangan berdasarkan program kerja yang ada dengan tidak menyenyampingkan permasalah pendidikan lainya yang mendesak dilakukan. Kemampuan aparatur akan terlihat dari tindakan-tindakan yang dilakukan untuk memaksimalkan segala anggaran yang tersedia di Dinas Pendidikan untuk dilaksanakan.

Potensi sumber daya yang dimiliki dalam implementasi kebijakan pendidikan juga tidak dapat lepas dari ketersediaan sarana penunjang seperti gedung sekolah, sarana pendukung kegiatan belajar, perkantoran dan sampai pada kejelasan informasi yang disampaikan dari Dinas kepada cabang dinas sampai ke sekolah yang ada. Dengan jumlah sekolah sebanyak 263 dimana terdapat 92 ruang kelas yang rusak berat serta adanya 12 cabang dinas yang tidak memiliki kantor. Kondisi ini belum termasuk dengan kurangnya gedung perpustakaan, laboratorium, peralatan kegiatan belajar mengajar seperti meja, kursi, ATK, alat peraga dan lain sebagainya. Kabupaten Kepulauan Talaud memiliki Penduduk usia sekolah dasar (7-12 tahun) 10. 457 jiwa dengan10.299 peserta didik, 115 sekolah dasar, 904 guru SD, 690 ruang kelas.

Dianalisis dari konsep implementasi yang dikemukakan oleh Smith (1973:202-205) menunjukkan bahwa terdapat beberapa hal yang perlu untuk diperhatikan, yang dalam hal ini kebijakan pendidikan dasar diimplementasikan yaitu idealised policy, targets,
Implementing organization serta Environmental factor sebagaimana amanat Undang-Undang Sistim Pendidikan Nasional No. 20 tahun 2003 dan Peraturan Pemerintah No. 47/2008 tentang wajib belajar 9 tahun.

Dipahami dari aspek Idealised policy terlihat pada program-program yang ditetapkan oleh Dinas Pendidikan Pemuda dan Olahraga Kabupaten Kepulauan Talaud dalam mengimplementasikan kebijakan pendidikan dasar. Pada Pasal 31 Undang-Undang Dasar 1945 mengatakan bahwa: (1) Setiap Warga Negara berhak mendapatkan pendidikan; dan pada pasal (2) Setiap Warga Negara wajib mengikuti Pendidikan Dasar dan Pemerintah wajib membiayainya; (3) Pemerintah mengusahakan Sistim Pendidikan Nasional yang meningkatkan keimanan dan ketaqwaan serta ahlak mulia dalam rangka mencerdaskan kehidupan bangsa; (4) Negara memprioritaskan anggaran pendidikan untuk memenuhi kebutuhan penyelenggaraan Pendidikan Nasional; serta (5) Pemerintah memajukan ilmu pengetahuan dan teknologi dengan menjunjung tinggi nilai-nilai agama dan persatuan bangsa untuk kemajuan peradaban serta kesejahteraan manusia.

Undang-Undang Nomor 20 Tahun 2003 Tentang Sistem Pendidikan Nasional yang menyata-kan bahwa Pendidikan Nasional berfungsi mengembangkan kemampuan dan membentuk watak serta peradaban Bangsa yang bermartabat dalam rangka mencerdaskan kehidupan Bangsa, bertujuan untuk berkembangnya potensi peserta didik agar menjadi manusia yang beriman dan bertaqwa kepada Tuhan Yang Maha Esa, berahlak mulia, sehat, berilmu, cakap, kreatif, mandiri dan menjadi warga Negara yang demokratis serta bertanggung jawab.

Perumusan Visi menunjuk pada Visi Pendidikan secara Nasional dipadukan dengan Visi Kabupaten yakni: "Terwujudnya Sistim Pendidikan sebagai Pranata sosial yang kuat, berwibawa menjadikan Kabupaten Kepulauan Talaud yang utuh, maju, berbudaya dan damai sejahtera." Misi:

1) Mengupayakan perluasan dan pemerataan kesempatan memperoleh pendidikan yang bermutu bagi seluruh masyarakat.

2) Membantu memfasilitasi pengembangan potensi anak secara utuh sejak usia dini sampai akhir hayat dalam rangka mewujudkan masyarakat belajar.

3) Meningkatkan kesiapan masukan dan kualitas proses pendidikan untuk mengoptimalkan pembentukan kepribadian yang bermoral.

4) Meningkatkan keprofesionalan dan akuntabilitas satuan pendidikan di Kabupaten Kepulauan Talaud.

5) Memberdayakan peran serta masyarakat/Stake Holders dalam penyelenggaraan pendidikan berdasarkan prinsip otonom dalam konteks Negara Kesejahteraan Republik Indonesia.

Untuk mewujudkan Misi sebagai penjabaran Visi ditetapkan strategi sebagai berikut: 
1) Pemerataan dan perluasan akses pendidikan

2) Peningkatan mutu, relevansi dan daya saing keluaran pendidikan

3) Peningkatan tata kelola, akuntabilitas dan citra publik pengelolaan pendidikan

Kebijakan yang telah ditetapkan untuk pembangunan pendidikan di Kabupaten Kepulauan Talaud dalam kurun waktu 5 Tahun yakni Tahun 2009-2014 adalah sebagai berikut :

1) Memperluas akses bagi anak usia 0-6 Tahun baik laki dan perempuan untuk memiliki kesempatan tumbuh dan berkembang secara optimal sesuai potensi melalui PAUD/TK.

2) Mengurangi beban biaya pendidikan bagi siswa keluarga miskin untuk penuntasan wajib belajar 9 Tahun.

3) Membentuk SD-SMP satu atap di daerah terpencil.

4) Memperluas akses bagi anak 7-15 Tahun yang belum terlayani di jalur Pendidikan Formal untuk memperoleh kesempatan layanan Pendidikan Non Formal.

5) Memperluas akses bagi penduduk Buta Aksara 15 Tahun keatas.

6) Memfasilitasi peran masyarakat dalam memperluas akses sekolah menengah.

7) Memperluas akses terhadap pendidikan di SMK sesuai kebutuhan.

8) Mengintegrasikan kesetaraan Gender terhadap proses layanan pendidikan.

9) Melaksanakan komunikasi, informasi dan edukasi untuk layanan khusus kepada masyarakat agar sadar tentang pentingnya pendidikan.

10) Pemanfaatan secara optimal sarana radio, televisi, komputer dan perangkat TIK lainnya untuk digunakan sebagai media pembelajaran dan untuk pendidikan jarak jauh.

Berkaitan dengan pendidikan dasar yang termuat pada Program Wajib belajar 9 Tahun telah ditetapkan:

1) Pembangunan dan Pemeliharaan Gedung Sekolah, Rumah Dinas Guru dan Penjaga Sekolah

2) Pembangunan Sarana Perpustakaan

3) Pembangunan/Pemeliharaan UKS

4) Pembangunan sarana air bersih dan sanitasi sekolah

5) Pembangunan Gedung SMP Satap

6) Pelatihan Kompetensi Siswa Berprestasi

7) Pembinaan minat, bakat dan kreativitas siswa.

8) Penyediaan Beasiswa Transisi.

Dari sepuluh kebijakan pendidikan di Kabupaten Kepulauan Talaud yang telah ditetapkan baru tiga kebijakan yang terlaksana yaitu 1) Memperluas akses bagi anak usia 0-6 Tahun baik laki dan perempuan untuk memiliki kesempatan tumbuh dan berkembang secara optimal sesuai potensi melalui PAUD/TK, 2) Mengurangi beban biaya pendidikan bagi siswa keluarga miskin untuk penuntasan wajib belajar 9 Tahun dan 3) Membentuk SD-SMP satu atap di daerah terpencil. Ketiga program kebijakan ini pun belum sepenuhnya terlaksana oleh karena keterbatasan anggaran yang dimiliki oleh Dinas Pendidikan Pemuda dan Olahraga.

Target groups merupakan target implementasi kebi-jakan dalam hal ini masyarakat Kabupaten Kepulauan Talaud yaitu partisipasi anak usia sekolah pada imple-mentasi kebijakan pendidikan dasar dan keaktifan dan peran serta anak dalam kegiatan sekolah. Dari data yang ada menunjukkan bahwa penduduk usia sekolah dasar yaitu pendudukak usia 7-12 tahun di Kabupaten Kepulauan Talaud berjumlah 10.457 anak usia sekolah dasar, sementara yang terdaftar sebagai murid sekolah dasar berjumlah 10.299 jiwa. Dari analisis yang dilakukan oleh Dinas Pendidikan Pemuda dan Olahraga Kabupaten Kepulauan Talaud menunjukkan bahwa angka partisipasi murni (APM) sekolah dasar 91.51\% dengan angka partisipasi kasar (APK) 98.46\%, dan angka partisipasi sekolah usia 7-12 tahun adalah 99.04\%. Keterlibatan anak usia sekolah (pendudukak usia 7-12 tahun di Kabupaten Kepulauan Talaud) tidak dapat dipisahkan dari peran serta orang tua. Dari data diatas menunjukkan bahwa target groups merupakan sasaran kebijakan atau pihak yang menerima kebijakan berada pada kategori baik yang perlu ditingkatkan oleh pemerintah dan masyarakat di Kabupaten Kepulauan talaud.

Implementing organization merupakan sumber daya yang dimiliki organisasi dan dipergunakan dalam imple-mentasi kebijakan. Dengan indikator: Sumber daya pegawai, Kemampuan pegawai, Kewenangan pekerjaan, Sumber daya dana dan prasarana. Suatu kebiajakan yang telah ditetapkan untuk selanjutnya dilaksanakan memerlukan organisasi pelaksana, sebab dengan organisasi itulah kewenangan dan berbagai sumber daya yang mendukung diberikan guna menterjemahkan konteks kebijakan tersebut dalam pelayanan publik. Peran aspek badan pelaksana dalam implementasi kebijakan pendidikan dasar kabupaten Kepulauan Talaud tidak dapat dipisahkan dari stuktur organisasi dan tata kerja Dinas Pendidikan Pemuda dan Olahraga Kabupaten Kepuluan Talaud selaku SKPD yang dipercayakan dalam implementasi kebijakan pendidikan dasar kabu-paten Kepulauan Talaud.

Pembentukan Dinas Pendidikan Pemuda dan Olah raga Kabupaten Kepulauan Talaud berdasarkan Peraturan Daerah Nomor 5 Tahun 2008 tentang pembentukan Dinas-Dinas sebagai unsur pelaksana tugas berdasarkan asas otonomi daerah. Susunan Organisasi Dinas Pendidikan, Pemuda dan Olahraga Kabupaten Kepulauan Talaud, terdiri dari Unsur Pimpinan: Kepala Dinas; Unsur Staf yaitu Sekretaris (Bagian Tata Usaha) yang membawahi tiga Sub Bagian Umum dan Perlengkapan, 
Kepegawaian dan Keuangan, dan Unsur Pelaksana yang terdiri dari Bidang-bidang Bidang Pendidikan Dasar, Bidang Pendidikan DIKMENTI, Bidang Pendidikan Diklusepora dan Bidang Perencanaan, Pelaporan dan Penjaminan Mutu serta Kelompok Jabatan Fungsional dan Unit Pelaksana Teknis Dinas (UPTD).

Bila dilihat dari desain strukturnya, organisasi Dinas Pendidikan, Pemuda dan Olahraga Kabupaten Kepulauan Talaud menganut model birokrasi mesin (Mintzberg, 1983 :163) yang dicirikan dengan padatnya tugas-tugas operasional rutin yang harus dicapai melalui spesialisasi, peraturan perundang-undangan yang sangat formal, tugas-tugas yang dikelompokkan ke dalam departemen-departemen fungsional, kekuasaan yang tersentralisasi, lingkup rentang kendali yang sempit dan pengambilan keputusan yang mengikuti rantai perintah.

Akan tetapi berdasarkan hasil pengamatan dan wawancara menunjukkan bahwa kegiatan yang dilakukan oleh Dinas Pendidikan, Pemuda dan Olahraga tidak berjalan sesuai dengan desain birokrasi mesin tersebut. Kenyataan ini terlihat dimana seksi sebagai operasional kegiatan belum mempunyai standart desain baku dalam menjalankan pekerjaannya sesuai dengan tugas pokoknya. Keadaan ini juga berlaku di level bidang. Dinas belum mempunyai prosedur dan mekanisme kerja untuk mencapai tujuan yang pasti dan jelas karena belum dilengkapi dengan prosedur operasional standar. Sebuah organisasi harus didukung dengan prosdur operasional standar sehingga dapat menyelenggarakan kegiatan secara efektif, efisien dan konsisten. Operasional prosedur merupakan pedoman yang berisi prosedur operasional standar yang ada dalam organisasi yang akan digunakan untuk memastikan bahwa setiap keputusan, tindakan maupun penggunaan fasilitas termasuk dana dilakukan dengan tepat dan benar.

Dalam desain struktur juga terlihat penempaatan Bidang Bidang Perencanaan, Pelaporan dan Penjaminan Mutu pada level middle line. Hal ini tidak sesuai dengan penjelasan yang dikemukakan oleh Mintzberg karena lembaga yang berada pada posisi middle line adalah lembaga yang melakukan fungsi pelaksanaan kebijakan sedangkan Bidang Bidang Perencanaan, Pelaporan dan Penjaminan Mutu adalah lembaga yang melakukan fungsi perencanaan. Perencanaan itu sendiri bukanlah pelaksanaan kebijakan akan tetapi pembuat kebijakan untuk dilaksanakan sehingga masuk fungsi pendukung atau supporting. Oleh karenanya jika mengacu pada pendapat Mintzberg maka bidang perencanaan seharusnya mesuk dalam unsure support staff yang dalam struktur berada di bawah sekretaris.

Akibat dari desain struktur yang ada ini membawa dampak pada manajemen operasional kegiatan Dinas Pendidikan, Pemuda dan Olahraga. Dampaknya adalah terjadinya proses pembuat kebijakan dengan alur terbalik. Kepala Dinas yang seharusnya mendapatkan masukan data dan informasi dan bahan untuk pembuatan perencanaan/kebijakan dari support staff justru mendapatkannya dari middle line (Bidang Perencanaan). Dengan kata lain middle line yang seharusnya berfungsi melaksanakan kebijakan Kepala Dinas justru menjadi lembaga pemasok data, informasi dan bahan untuk pembuatan kebijakan. Demikian pulah halnya dengan pelaporan dan penjaminan mutu termasuk pengelolaan data kependidikan.

Pembentukan Dinas Pendidikan Pemuda dan Olah raga tersebut diatas menunjukan bahwa dinas tersebut bukan hanya menangani pelayanan pendidikan akan tetapi juga pelayanan kepemudaan dan olehraga dengan anggaran yang diberikan sebesar Rp. 51.288.160.508,00 dengan capaian realisasi sebesar Rp. 43.437.295.948,00. Pada dasarnya, para pelaksana kebijakan mungkin mengetahui apa yang dilakukan dan mempunyai cukup keinginan serta sumber-sumber untuk melakukannya, tetapi dalam pelaksanaannya mereka mungkin masih terhambat oleh struktur-struktur organisasi dimana mereka menjalankan kegiatan tersebut termasuk besarnya lingkup permasalahn yang harus diimplementasikan. Menurut Edwards III (dalam Winarno, 2002: 150), ada dua karakteristik dari birokrasi yang menghambat implementasi kebijakan, yakni prosedur-prosedur kerja atau ukuran-ukuran dasar yang sering disebut sebagai Standar Operating Procedural (SOP) dan fragmentasi. Hal ini kemungkinan disebabkan adanya keinginan untuk keseragaman terhadap pelaksanaan kebijakan ataupun pertentangan kepentingan. Sehingga jika suatu badan yang mempunyai fleksibilitas yang rendah dalam misi-misinya, maka badan itu akan berusaha mempertahankan esensinya dan besar kemungkinan akan menentang kebijakan-kebijakan baru yang membutuhkan perubahan. Walaupun SOP dapat menghambat implementasi kebijakan, namun demikian organisasi-organisasi dengan prosedur-prosedur perencanaan dan kontrol yang besar atas program yang luwes dan mungkin dapat menyesuaikan dengan tanggungjawab yang baru.

Observasi lapangan menunjukan dimana banyaknya permasalahan pendidikan dalam lingkup tanggungjawab Dinas Pendidikan, Pemuda dan Olahraga antara lain:

1) Biaya Rutin harus ditingkatkan sebab dari Cabang Dinas tidak pernah diminta usulan program prioritas serta besaran dana tetapi DPPKAD/TAPD langsung mematok/menetapkan besaran dana Rp. 30 juta/ Cabang Dinas tanpa melihat tingkat kesulitan, keterisolasian serta letak geografis kecamatan.

2) Kantor Cabang Dinas yang sekarang dipakai adalah Rumah Dinas Guru

3) Kacabdin dalam pemantauan ke sekolah-sekolah dengan biaya sendiri

4) Tidak optimalnya pelayanan administrasi kantor secara umum karena kurang tersedianya kebutuhan 
administrasi perkantoran.

5) Khusus pelayanan Kenaikan Pangkat sering bermasalah/ terlambat karena timbulnya pungutan yang tidak biasanya.

Perilaku pada dasarnya berorientasi pada tujuan (goal oriented). Dengan perkataan lain, perilaku kita pada umumnya dimotivasi oleh suatu keinginan untuk mencapai tujuan tertentu. Tegasnya bahwa sikap dan perilaku sangat tergantung pada motif, tujuan dan aktivitas yang membentuk perilaku. Sebagai suatu program, suatu kebijakan pada umumnya melibatkan dua kelompok utama, yaitu para pelaksana program dan kelompok yang menjadi sasaran program atau kebijakan. Sikap pelaksana adalah komitmen dari para pelaksana untuk melakukan perbuatan sesuai dengan kebijakan yang ditetapkan. Perilaku patuh seorang pelaksana kebijakan tidak selamanya menunjukkan loyalitas yang bersangkutan terhadap apa yang menjadi kewajibannya, tetapi berhubungan dengan penilaian individu yang bersangkutan terhadap pandangan untung ruginya yang akan diperoleh jika mengikuti ketentuan-ketentuan yang di atur dalam kebijakan.

Peran pengawasan sangat dibutuhkan untuk menjamin efektivitas implementasi kebijakan. Disamping itu pengorganisasian perilaku melalui program juga berpengaruh dan menentukan sikap pelaksana. Implementasi kebijakan yang melibatkan banyak organisasi pelaksana relatif lebih sulit dilaksanakan dibandingkan dengan implementasi kebijakan yang hanya melibatkan satu organisasi. Implementasi kebijakan yang melibatkan sejumlah badan pelaksana yang bertanggunjawab kepada atasan yang berlainan seringkali melahirkan pertentangan diantara petunjuk yang diberikan oleh masing-masing pejabat. Dalam situasi seperti ini pelaksana akan cenderung mengikuti petunjuk-petunjuk yang diberikan oleh atasannya masing-masing atau mengikuti petunjuk dari atasan yang mempunyai pengaruh paling kuat atas eksistensi pelaksana (penilaian prestasi, jabatan, kepangkatan, keuangan) dalam jangka panjang.

Implementasi boleh gagal sebab para pelaksana menolak apa yang mereka duga. Konflik sikap terjadi sebab bawahan pelaksana menolak tujuan dari atasan. Rcsistensi tersebut di pandang melanggar harga diri personal pelaksana atau loyalitas ekstra organisasi, melanggar kepentingan pribadi mereka, atau mengubah perbuatan organisasi dan bermaksud mempertahankan prosedur para pelaksana. Sikap para pelaksana dipengaruhi oleh sumber-sumber kebijakan, komunikasi interorganisasi dan aktifitas pelaksanaan, karakteristik badan pelaksana, lingkungan dan pelaksana.

Faktor sikap pelaksana kebijakan berpengaruh terhadap berhasil dan tidaknya suatu implementasi kebijakan, karena seringkali kegagalan implementasi kebijakan disebabkan para pelaksana tidak memahami sepenuhnya atas kebijakan yang dihadapi, terlebih apabila menolak tujuan yang terkandung dalam kebijakan tersebut. Untuk mengatasi hal itu, maka para pelaksana dituntut memiliki keahlian, dedikasi dan pemahaman tentang tujuan kebijakan. Sikap apara pelaksana juga akan berdampak pada tanggungjawab yang diberikan dalam pelaksanaan tugas kaitannya dengan isi dan batas pertanggungjawaban. Dalam pertanggungjawaban terdapat dua aspek yaitu hukum dan pencapaian sasaran/tujuan. Lemahnya tanggung jawab para pelaksana implentasi kebijakan akan mengakibatkan tujuan kebijakan tidak tercapai.

Dalam wawancara yang dilakukan kepada sejumlah kepala seksi diperoleh penjelasan bahwa semangat untuk menjalankan tugas dan tanggung jawab sebagaian besar belum menjalankan pelayanan secara baik termasuk dalam menjalankan kebijakan anggaran pendidikan. Sikap pelaksana dimaksudkan adalah sikap atau per-spektif para implementator kebijakan. Perlu adanya kesamaan sikap atau perspektif antara para pengambil kebijakan (decision makers) atau formulator kebijakan, dengan para implementator kebijakan. Dikatakan bahwa para irnplernentator (birokrat) secara umum mem-punyai kemungkinan menyimpang dalam sikap dan perspektifnya tentang kebijakan, dan ini dapat menjadi penghambat utama bagi keefektifan implementasi kebijakan.

Hal ini dapat terjadi karena adanya pemisahan antara para pengambil kebijakan/keputusan, dengan para pelaksana kebijakan (implementator) yang memiliki kebebasan (independence) untuk menafsirkan makna, serta menentukan cara menjalankan kebijakan. Ada beberapa pertanyaan mendasar lebih lanjut dari keadaan di atas, yaitu: apa yang menyebabkan perbedaan sikap pandang tentang kebijakan antara pernbuat kebijakan dengan pelaksana kebijakan, mengapa para pimpinan unit pelaksana kebijakan mempunyai kemampuan yang terbatas untuk menempatkan petugas pelaksana yang lebih responsif untuk rnenjalankan programnya, dan bagaimana mempengaruhi sikap petugas pelaksana melalui pemberian intensif sebagai penghargaan (rewards).

Ada beberapa hal yang menyebabkan terjadinya perbedaan sikap/perspektif dari petugas pelaksana kebijakan. Yang pertama adalah sikap pandang atau cara pandang sempit, yang menganggap bahwa sektor pekerjaannya sangat penting, dan lebih penting daripada sektor lainnya. Oleh karena itu, mereka akan selalu berlomba untuk memperoleh dukungan dari pimpinan bagi perkembangan dan kelangsungan organisasinya. Kondisi inilah yang menyebabkan terjadinya perbedaan sikap pandang tentang kebijakan antara petugas pelaksana dengan pimpinan tidak langsung, maupun antar petugas pelaksana dari sektor pekerjaan yang lain, serta timbulnya sikap pandang yang sempit tentang kepentingan organisasi.

Hal yang kedua adalah sikap pandang pelaksana yang lebih mengutamakan perolehan penghasilan 
untuk kesejahteraan mereka sendiri. Disini dapat terjadi penyalahgunaan kewenangan dalam menjalankan kebijakan, dengan tujuan untuk meningkatkan kesejahteraan mereka sendiri, sehingga kebijakannya itu sendiri menjadi terabaikan, atau berjalan tapi tidak sesuai dengan tujuan. Hal yang ketiga yang dapat menyebabkan hambatan pelaksanaan kebijakan dan faktor sikap pelaksana adalah ketidakmampuan pimpinanunit pelaksanauntukmemilih danmenempatkan petugas pelaksana yang dinilai lebih tanggap terhadap perintah pimpinannya. Berdasarkan uraian tersebut dapat dikatakan bahwa aparat pelaksana sangat menentukan keberhasilan implementasi kebijakan. Untuk itu aparat pelaksana harus ditingkatkan keterampilannya sehingga dapat mengimplementasikan kebijakannya sesuai dengan suasana kebutuhan pada saat kebijakan itu dibuat.

Environmentalfactormerupakanfaktorlingkungan internal dan eksternal yang dapat mempengaruhi implementasi kebijakan. Dengan indikator kondisi wilayah, peran lembaga legislative yang membidangi pendidikan, LSM Pendidikan, social ekonomi Kabu-paten Kepulauan Talaud. Lingkungan kebijakan merupakan faktor penting terhadap keberhasilan suatu kebijakan dalam implementasinya. Jika kondisi lingkungan positif maka kebijakan akan menghasilkan dukungan positif pula, situasi ini akan membiat mereka berpartisipasi dalam mensukseskan lingkungan kebijakan. Sebaliknya jika lingkungan berpandangan negatif maka akan mengakibatkan benturan sikap sehingga proses implementasi terancam kurang berhasil atau bahkan gagal sama sekali.

Keberadaan Kabupaten Kepulauan Talaud yang masih kental dengan budaya dimana Kepulauan Talaud mempunyai latar sosial-budaya dan historis yang unik dan kaya. Tidaklah mengherankan karena berdasarkan kajian arkeologis, kepulauan Talaud sudah dihuni sejak ribuan tahun lalu. Ada sejumlah versi tentang asalmuasal kata Talaud dan Porodisa. Hal mana memerlukan kajian dari para pakar di bidangnya. Namun, satu hal yang perlu dicatat adalah adanya konsepsi kesatuan dari warga kepulauan Talaud. Kesatuan inilah yang sampai saat ini selalu dipegang teguh masyarakat didalam menjalankan kehidupannya.

Budaya gotong royong dalam pelaksanaan pembangunan di segala bidang yang ada di daerah termasuk di desa telah ada sejak dahulu kalah di Kabupatern Kepulauan talaud. Selain itu pula situasi masyarakat yang masih memiliki keterkaitan keluarga merupakan suatu penyebab kebersamaan yang mengikat masyarakat dalam saling membanu. Akan tetapi kondisi sosial budaya masyarakat agak bertolak belakang dengan lingkungan politik daerah. Dalam hal penyusunan dan pengusulan serta penetapan anggrana pendidikan, Dinas Pendidikan, Pemuda dan Olahraga diperhadapkan dengan situasi yang merumitkan dimana untuk mendapatkan anggaran yang diharapkan harus melakukan tindakan loby politik sebagai akibat dari adanya keterbatasan anggaran daerah yang harus dibagi pada semua aspek pelayanan. Selain itu pula dengan situasi daerah yang mengalami goncangan politik pasca pergantian Bupati kepada Penjabat Bupati membawa perubahan pada alur kebijakan yang dijalankan.

Betapa tinggi konflik yang timbul dalam penganggaran, yaitu dalam hal-hal yang berkaitan dengan ketepatan alokasi sumber-sumber sosial, pengajuan titiktitikyang fokal yang dianggap penting yang perlu dijadikan bahan pertimbangan pemerintah dalam pengambilan keputusan, memperjelas hubungan-hubungan politik dan memberikan gambaran konflik-konflik politik, anggaran sebagai alat untuk menjamin terlaksananya akuntabilitas.

Sementara itu kondisi ekonomi masyarakat erat kaitannya dengan demografis daerah dimana Selain karakterristiknya sebagai kepulauan, Kabupaten Talaud memiliki tiga karakteristik lainnya, yakni sebagai "daerah perbatasan","daerah tertinggal dan terisolasi", dan"daerah rawan bencana alam". Ciri dan karakter kepulauan jelas tampak pada luas lautan yang jauh lebih besar dari luas daratan atau pulau-pulaunya. Karakteristiknya sebagai daerah perbatasan dipertegas dalam Peraturan Presiden Nomor 7 Tahun 2005 Bab 26. Miangas sebagai pulau paling utara di wilayah Kabupaten Kepulauan Talaud jaraknya kurang lebih 52 mil dari Kota Davao dan 48 mil dari Tanjung St. Agustin Mindanao, Filipina. Sedangkan jaraknya dengan Karatung, ibukota Kecamatan Nanusa, 58 mil; dengan Melonguane, ibukota Kabupaten, 122 mil; dengan Manado, ibukota Provinsi, 307 mil.

Ketertinggalan serta keterisolasiannya tidak hanya terbuktikan lewat letak dan posisi geografis, tetapi terutama karena keterbatasan prasarana dan sarana di bidang ekonomi, sosial-budaya, pertahanan keamanan, perhubungan darat, laut dan udara, telekomunikasi dan informasi. Karakteristik ini diperkuat oleh Keputusan Menteri Pembangunan Daerah Tertinggal Nomor 1 Tahun 2005 yang menetapkan dua wilayah kabupaten di Provinsi Sulawesi Utara yakni Kabupaten Kepulauan Sangihe dan Kabupaten Kepulauan Talaud sebagai "daerah tertinggal".

Kondisi lingkungan kebijakan sangat berpengaruh terhadap efektivitas implementasi kebijakan (Wahab, 1997:93 94). Lebih lanjut dijelaskan bahwa perbedaan kondisi tersebut dapat mempengaruhi persepsi mengenai kadar pentingnya masalah yang akan ditanggulangi oleh suatu peraturan, jika pada waktu tertentuadamasalah sosial yang lebih penting maka kemungkinan dukuugan politik akan menurun secara drastis. Keberhasilan implementasi mungkin akan lebih sulit mengingat perbedaan tersebut, perbedaan tersebut akan menimbulkan desakan untuk membuat aturan yang lebih luwes dan memberi keleluasaan yang lebih kepada implementor

Perlu dipertimbangkannya pembahasan kondisi lingkungan dalammengimplementasikankebijakantidak 
dapat dilepaskan oleh apakah sumber-sumber ekonomi yang berguna dalam organisasi pelaksana tersedia untuk mendukung keberhasilan implementasi; sejauh mana kondisi ekonomi dan sosial dipengaruhi oleh peiaksanaan kebijakan; apakah opini publik yang menonjol sesuai dengan isu kebijakan; apakah elit mendukung atau menentang implementasi kebijakan; apakali karaktenstik dari pendukung organisasi pelaksana, menentang atau mendukung kebijakan; apakali karaktenstik dari pendukung organisasi pelaksana, menentang atau apakah kelompok kepentingan telah dimobilisasi didalam mendukung atau menentang suatu kebijakan.

\section{SIMPULAN}

Dari hasil penelitian dan pembahasan maka dapat disimpulkan bahwa implementasi kebijakan pendidikan dasar di Kabupaten Kepulauan Talaud berdasarkan dimensiidealised policy, targets, Implementing organization serta Environmental factorbelum sepenuhnya berjalan dengan baik pada dimensi idealised policy, Implementing organization dan Environmental factork husunya lingkungan lembaga politik. Keberhasilan dalam implementasi kebijakan pendidikan dasar di Kabupaten Kepulauan Talaud berada pada dimensi target group yang dalam hal ini peserta didik yang termasuk didalamnya peran dari orang tua. Keberhasilan dalam implementasi kebijakan pendidikan dasar melalui siswa dan peran orang tua banyak berkaitan dengan peran orang tua dalam mendukung kelancara kegiatan belajar mengajar. Sementara itu environmental factor melalui lingkungan politik dari lembaga legislative daerah sebagai dimensi yang belum banyak terlihat perannya dalam banyak membantu pencapaian pelaksanaan kebijakan pendidikan dasar. Dari simpulan yang ada maka disarankan untuk melakukan perbaikan pada penyusunan dan penetapan program yang sesuai kebutuhan untuk mengimplementasikan kebijakan pendidikan dasar seperti ketersediaan tenaga pendidik, ketersediaan sarana kegiatan pembelajaran dan biaya operasional, menempatkan pejabat yang tepat sesuai dengan kemampuan dan keahlian pada bidang pendidikan dasar, melakukan analisis lebih lanjut mengenai lemahnya dukungan lingkungan politik (DPRD) pada kebijakan pendidikan dasar.

\section{DAFTAR PUSTAKA}

Mintzberg, H. 1983. Structures In Fiver. Designig Effective Organizations. Prentice Hall. New Jersey.

Smith Thomas B. 1973. The Policy Implementation Process. Policy Sciences 4,pp 197-209. Elssevier Scientific Publishing Compani. Amsterdam : Printed in Scotland.

Wahab, Abdul. Solichin, 1997. Evaluasi kebijakan Publik. Penerbit FIA UNIBRAW dan IKIP Malang.

Winarno, Budi. 2002. Teori dan Proses Kebijakan Publik. Yogyakarta: Media Pressindo

Undang-Undang Nomor 20 tahun 2003 Tentang Sistim Pendidikan Nasional

Peraturan Pemerintah Nomor 47 Tahun 2008 tentang Wajib Belajar Sembilan Tahun.

Peraturan Daerah Kabupaten Kepulauan Talaud Nomor 5 Tahun 2008 tentang Pembentukan Dinas-Dinas Sebagai Unsur Pelaksana Tugas Berdasarkan Asas Otonomi Daerah. 